\title{
IL-12 FAMILY CYTOKINES: GENERAL CHARACTERISTICS, PATHOGENIC MICROORGANISMS, RECEPTORS, AND SIGNALLING PATHWAYS
}

\author{
PAYAM BEHZADI ${ }^{1}$, ELHAM BEHZADI ${ }^{1}$, REZA RANJBAR ${ }^{2 *}$ \\ ${ }^{1}$ Department of Microbiology, College of Basic Sciences, Shahr-e-Qods Branch, \\ Islamic Azad University, Tehran, Iran \\ ${ }^{2}$ Molecular Biology Research Center, Baqiyatallah University of Medical Sciences, \\ Tehran, Iran
}

(Received: 15 July, 2015; accepted: 14 December, 2015)

\begin{abstract}
Among a wide range of cytokines, the Interleukin 12 (IL-12) family has its unique structural, functional, and immunological characteristics that have made this family as important immunological playmakers. Because of the importance of IL-12 heterodimeric cytokines in microbial infections, autoimmune diseases, and cancers, the authors of this literature discuss about the general characteristics of IL-12 family members, the interactions between IL-12 cytokines and pathogenic microorganisms, the interleukins receptors and their strategies for selecting different signalling pathways. IL-12 and IL-23 are similar in p40 subunits and both are involved in proinflammatory responses while, IL-27 and IL-35 contribute to anti-inflammatory activities; however, IL-27 is also involved in pro-inflammatory responses. There are some similarities and dissimilarities among IL-12 family members which make them a unique bridge between innate and adaptive immune systems. The bioactivities of IL-12 family indicate a brilliant promise for their applications in different fields of medicine. The members of IL-12 family are candidate for several therapeutics including gene therapy, cancer therapy, tumour therapy, and vaccination. To have an accurate diagnostic technique and definite treatment regarding to infectious diseases, the playmakers of IL-12 family as effective criteria together with microarray technology are the best choices for current and future applications.
\end{abstract}

Keywords: IL-12, IL-23, IL-27, IL-35

\footnotetext{
*Corresponding author; E-mail: ranjbarre@gmail.com
} 


\section{Introduction}

The term Cytokine is composed of Cyt/o (Cell) and Kin/e (movement) [1]. This term involves a wide range of soluble components such as glycoproteins of monokines, lymphokines, interferon- $\gamma($ IFN- $\gamma$ ) and interleukins (ILs) which are produced via a vast number of cell types. The secreted proteins of cytokines affect their targets throughout different immunological pathways comprised of apoptosis (programmed cell death/cell suicide), growth, development and differentiation. The activities of cytokines are directly influenced by a series of regulators and feedbacks. The nonstructural proteins of cytokines are categorized in accordance with their biological functions. The majority of cytokines are secreted when an infection/disease is trying to invade the human host and immune system. Therefore, cytokines are recognized as the body's feedback against strangers and stresses [2-7].

According to previous surveys, ILs involve a vast range of structures, functions and diversity to have a considerable role in modulating human immune system responses against undesirable conditions such as infectious diseases, autoimmune diseases and cancers. As a duty, ILs contribute to the processes of differentiation, growth, progression and production of immune cells for protecting host body's from strangers like pathogenic microorganisms including bacteria, fungi, protozoa, helminths and viruses. Besides, the anti-inflammatory and pro-inflammatory activities, allergic reactivities, induction of different types of immune regulations and secretions within the immune cells' system are dominated by ILs. The aforementioned characteristics relating to ILs indicate that, they are capable to influence different generations and types of immune system cells as a powerful defence system against pathogens. The incredible occurrence is that, cytokines are able to distinguish microbial microflora from the other pathogens. These advanced abilities of ILs, represent them as invaluable biological playmakers within the human immune system. There are over than 40 types of ILs with different properties. The IL-12 family members are known as quite distinct cytokines rather than others; because of their unique characteristics of heterodimeric structures [3, 8-13].

The processes of secretion, resolution, activation and termination of cytokines including IL-12 family members are directly in association with transcriptional, post-transcriptional, translational and post-translational factors. These factors determine and programme different regulons including transcriptional, post-transcriptional, translational and post-translational regulons. The transcriptional regulons trigger genes to express mRNA molecules encoding different immunofunctional proteins. So, the process of gene expression regulation is known as transcription. The expression of cytokines such as IL-12 family 
members is performed throughout the process of DNA molecules conversion into mRNAs. This process is followed by another step that is considered as a very fine regulated procedure in which the hidden data within mRNA molecules are translated into a vast range of immunological responses such as cytokines secretion. Thus, the transcription phase involves processed mRNAs encompassing caps and polyadenylated tails. It must be considered that, the mRNA molecules are increased in parallel with cytokines secretion [14-16].

There are some important approaches which control the process of mRNA translation. The presence, and absence of mRNAs and the translation inhibition of mRNA molecules are regarded as particular factors which determine and programme post-transcriptional regulons. So, the post-transcriptional components dominate the process of genes expressions which are relating to immunological reactions. In other word, the post-transcriptional pathway regulates the running mRNA molecules from nucleus, localization of mRNAs within cellular cytoplasm, the beginning of translation step and disappearance of mRNAs [15-18].

According to recent investigations, initiation and termination of immunological reactions including expression of anti-inflammatory and pro-inflammatory ILs like IL-12 family members are also regulated by transcription and posttranscription processes. The beginning and termination of cytokines secretion may lead to occurrence of serious damages within tissues. So, aforementioned processes are achieved in a quick and fast duration. Today, our knowledge about mRNAs and the related processes has risen up via advanced molecular technology of microarray. This reliable, reproducible, rapid and accurate technique is effective for detecting and identifying DNA and RNA molecules [19-22].

Because of the noticeable properties of IL-12 family members against infectious diseases as important immunological playmakers regarding to human immune system, the main aspect of the present review literature is to focus on characteristics of the family members of IL-12.

\section{IL-12 family members}

The IL-12 family members are consisted of IL-12, IL-23, IL-27, and IL-35. They contribute to regulation of immune system against infectious diseases, autoimmune diseases and cancers. The main sources of triad ILs involving IL-27, IL-23 and IL-12 are active antigen presenting cells (APCs) while the IL-35 is produced by activated and resting regulatory $\mathrm{T}$ (Treg) cells including thymus originated Tregs (natural Treg (nTreg) cells) and the peripheral induced Treg (iTreg) cells in high level and IL-35-producing regulatory B (Breg) cells in low level. The quadruple group of IL-12 family converts the immature CD4 ${ }^{+} \mathrm{T}$ cells 


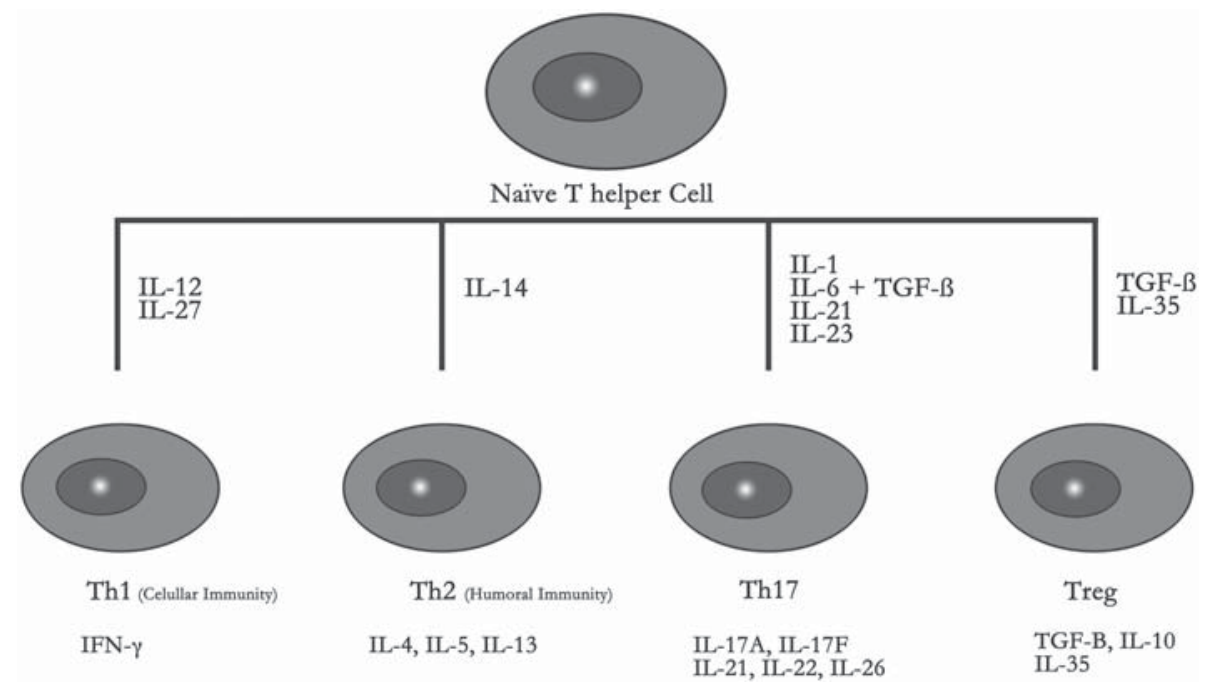

Figure 1. Naïve T cell differentiation into four types of Th cells and their related cytokine secretions. The naïve Th cells are able to be induced and make several Th cell subsets. IL-12 and IL-27 activities result in induction of INF- $\gamma$ producing Th1 cells.

The Th1 cells are known as mediators of cellular immune system. IL-14 is Th2 cells inducer. The triggered humoral immune system mediator of Th2, is able to produce ILs-4, 5, and 13. 5 ILs including IL-1, IL-6+TGF- $\beta$, IL-21, and IL-23 are important inducers of Th17 cells. It must be mentioned that IL-23 is known as a Th17 stabilizer rather than Th17 inducer. The Th17 cells are able to produce a wide range of ILs including IL-17A, IL-17-F, IL-21, IL-22, and IL-26.

TGF- $\beta$ and IL-35 are Treg inducers. However, IL-35 is also known as a Treg production

into memory $\mathrm{T}$ cells and $\mathrm{T}$ helper $(\mathrm{Th})$ cells in which the innate part of defence system links into the adaptive immunity. Actually, some IL-12 cytokines such as IL-12 and IL-23 are the main stimulators for memory T cells proliferation. However, IL-12 cytokines normally influence the duration of effectors responses. Besides, these cytokines are able to polarize the innate or native T cells [23-31].

The members of IL-12 are all involved in cytological and physiological activities in association with $\mathrm{CD}^{+}{ }^{+} \mathrm{Th}$ cells. Indeed, naïve Th cells are able to be differentiated into four major categories of Th1 (producing IFN- $\gamma$ ), Th2 (producing IL-4, IL-5, and IL-13), Th17 (producing IL-17A, IL-17F, IL-21, and IL-22, IL-26) and Treg (producing transforming growth factor (TGF)- $\beta$, IL-10, and IL-35) (Fig. 1). IL-12 and IL-23 are necessary cytokines for Th1 and Th17 cells activities [12, 32-35].

The fourfold members of IL-12 family have some similarities and dissimilarities in their structures and functions. Each member of IL-12 family is individually discussed below: 


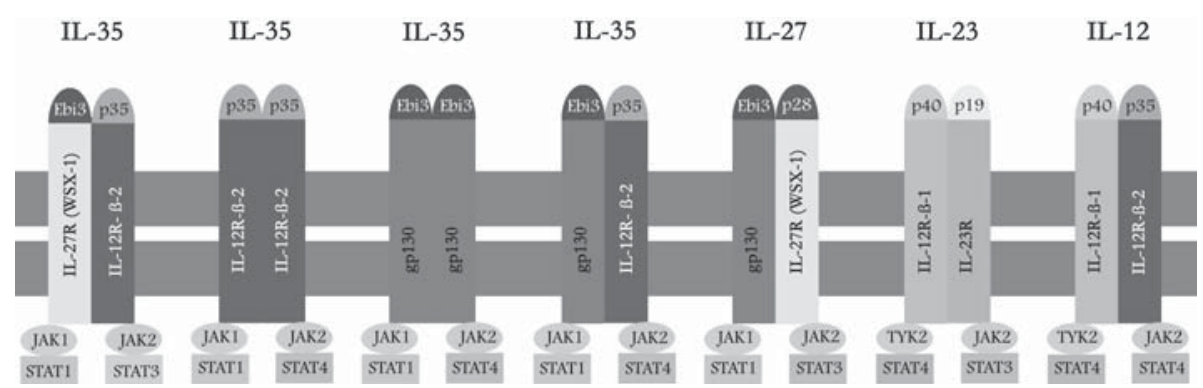

Figure 2. The structures of IL-12 family, related receptors and signalling pathway in an immune cell.

The IL-12 family is consisted of IL-12, IL-23, IL-27 and IL-35. The IL-12 (p35/p40) sends signals through its receptor (IL-12R- $\beta 1 /$ IL-12R- $\beta 2$ ), TYK2/JAK2, and STAT4 molecules.

The IL-23 (p19/p40) utilizes its receptor (IL-12R- $\beta 1 /$ IL-23R) for sending signals through TYK2/JAK2, and STAT3/STAT4 signalling pathway.

The IL-27 (p28/Ebi3) and the related receptor (gp130/IL-27R (WSX-1)) use JAK1/JAK2, and STAT1/STAT3 molecules as a regular signalling pathway for signal casting.

IL-35 (p35/Ebi3) possesses four different receptors (gp130/IL-12R- $\beta 2$ (heterodimers)), gp130/gp130 (homodimers), IL-12R- $\beta 2 /$ IL-12R- $\beta 2$ (homodimers), and IL-27R (WSX-1)/IL-12R- $\beta 2$ (heterodimers). The first three receptors apply JAK1/JAK2, and STAT1/STAT4 and the last receptor uses JAK1/JAK2, and STAT1/STAT3 as appropriate signalling pathways for moving the subjected signals.

\section{IL-12 and general characteristics}

Trinchieri [82] and Gately et al. [70] are the first scientists that discovered cytokine of IL-12. IL-12 is known as one the most significant cytokines that regulates immune system responses. The $70 \mathrm{kDa}$ pro-inflammatory molecule of IL-12 works as a powerful response to pathogenic microorganisms. B cells, dendritic cells (DCs) and macrophages (MФs) are the main resources for IL-12 cytokine. Structurally, IL-12 is consisted of two subunits of $\alpha$ (IL-12p35) and $\beta$ (IL-12p40) weighting $35 \mathrm{kDa}$ and $40 \mathrm{kDa}$, respectively (Fig. 2). The $\alpha$-spiral structure subunit resembles IL- 6 and the $\beta$ is similar to IL-6 receptor. Each subunit is produced by a separate chromosome and the subunits are linked via covalent bonds [36-38].

According to the recent studies, IL-12 $\alpha$-subunits are produced in different type of cells but in low level. On the other hand, the $\beta$-subunits are secreted only within limited cells that are able to produce IL-12p70 including activated DCs, MФs, monocytes and neutrophils. Hence, to form an active IL-12 cytokine; there is a need for simultaneous co-expression of IL-12p35, IL-12p40, and IL-12p70 within a same home cell. The level of IL-12p40 is up to 1000 rather than IL-12p35. So, always there is a high amount of unbound and free molecules of IL-12p40 within the cells [39-41]. 
Recent studies decipher the transcriptional and post-transcriptional regulations regarding to IL-12 family members. The combination of myeloid differentiation primary response gene 88 (MyD88) with toll-like receptors (TLRs) (excluding TLR3) activates nuclear factor- $\kappa \mathrm{B}(\mathrm{NF}-\kappa \mathrm{B})$. On the other hand, the simultaneous presence of IFN-Regulatory factor 5 (IRF5) with MyD88 and NF$\kappa \mathrm{B}$ provides IL-12 family members producing genes to express [42-44].

The contribution of TLR ligands prepares an appropriate situation for transcriptional regulations. Hence lipopolysaccharide (LPS), a bacterial TLR ligand is able to rearrange the configuration of a particular region (nucleosome-1) relating to p40 gene promoter. The new arrangement of the region is prompt for activation of several transcription factors including CCAAT/enhancer binding protein $(\mathrm{C} / \mathrm{EBP})$. NF- $\mathrm{NB}$ is an essential factor for activating promoter during the presence of LPS. The consensus region of NF- $\kappa \mathrm{B}$, ETS links ETS-2 to PU.1 to make them ready for creating a complex with some other components such as c-Rel, some of IFR members, and IFN-consensus sequence binding protein (ICSB). The basis of transcriptional and translational processes of p35 and p40 genes expressions is the same with some differences in details; however, a main functional dissimilarity is distinguished regarding to p35 and p40 genes expressions. The common enzyme of extracellular signal regulated kinase mitogen activated protein kinase (ERKMAPK) between p35 and p40 genes expressions processes acts with different attitudes. ERKMAPK is known as a halter in p40 gene expression but as a restrictive agent in p35 gene expression [45-47].

The processes of post-transcriptional and post-translational in association with p35 and p40 occur within the cell milieu but in different pathways. The cleavage of p40 is performed once during the entrance into the endoplasmic reticulum (ER), while the p35 is cleaved twice within the ER milieu. The transcriptional, post-transcriptional, and post-translational processes pertaining to the other IL-12 family members subunits are as the same with some dissimilarity in details [48-50].

\section{IL-12 and pathogenic microorganisms}

Several surveys show a high induction of IL-12 in the presence of microbial agents such as bacteria (Gram positive and Gram negative), fungi, helminths, protozoa, and viruses. The microbial components act as TLR ligands. The signalling process between microbial components and their related TLRs leads to induction of IL-12 via innate immune system. TLRs are recognized as important balancers for secretion of IL-12 family members. Bacterial pieces like DNA, LPS, peptidoglycan and lipoteichoic acid are important inducers of IL-12. The 
adaptive system encompasses to produce IL-12 via CD40 and APCs attachments which are mediated by $\mathrm{T}$ cells CD40L receptors [42, 51-59].

There is a two-way positive interaction between IL-12 and IFN- $\gamma$. The secretion of IL-12 leads to production of IFN- $\gamma$ by Natural killer (NK) and T cells. The axis of IL-12/IFN- $\gamma$ regulates immunological reactions. Moreover, IL-12 increases the cytotoxicity of cytotoxic T and NK cells and stimulates T cells differentiation into Th1 effectors. These characteristics relating to IL-12, support the importance of IL-12 in cell mediated pathways within immune system. Simultaneously, the secretion and dissemination of IFN- $\gamma$ triggers the production of IL-12; which is an appropriate mechanism against pathogenic microorganisms such as Listeria monocytogenes, Mycobacterium tuberculosis, Candida albicans and Leishmania major. In other word, IFN- $\gamma$ activates phagocytes to achieve their bactericidal activities throughout the production of more IL-12 and phagocytosis. IL-12 is known as an effective biological inhibitor for IL-4, IL-10, IL-11, and IL-13 [33, 60-66].

The absence of IL-12 predisposes human cells for invasion of intra-M $\Phi$ pathogenic microorganisms such as Francisella tularensis, Klebsiella pneumoniae, Mycobacteria, and Salmonella. Stimulation of TLR3 (viral ligands), TLR4 (bacterial (Gram negative bacteria) ligands) and TLR8 (viral ligands) gives rise to induction of IL-12p35. Stimulation of aforementioned TLRs and TLR2 (fungal and bacterial (Gram positive) ligands) induces IL-12p40 subunit [52, 67-69].

\section{IL-12 receptors and signalling pathway}

IL-12 affects the immune system activities throughout binding to IL-12 receptors (IL-12Rs). The IL-12R is composed of two subunits of $\beta 1$ and $\beta 2$ which their genes are situated on two different chromosomes. The $\beta 1$ links to IL-12p40 and the $\beta 2$ binds to IL-12p35 (Fig. 2). The role of $\beta 2$-subunit is to convert signals received from IL-12. The highest affinity between IL-12 and IL-12R is performed when all the IL-12 and IL-12R subunits are actively present $[12,70]$.

Each subunit of IL-12R has its distinct biological activity. The cytoplasmic end of IL-12R- $\beta 1$ which is missing the three tyrosine amino acids within intracellular domain, is bound to Tyrosine kinase-2 (TYK2). The mammalian Janus kinases (JAKs) involve four members including JAK1, JAK2, JAK3 and TYK2. The lack of tyrosine residues within IL-12R- $\beta 1$ subunit prevents the contribution of $\beta 1$-subunit in the process of signal transducing. The key role of IL$12 \mathrm{R}-\beta 1$ is contributing in ligand binding process. In contrast, the IL-12R- $\beta 2$ which binds to JAK-2 contributes in signalling transduction process throughout the three amino acid residues of tyrosine. These tyrosine amino acids are recog- 
nized as a suitable binding site for signalling and triggering transcription 4 (STAT4) (Fig. 2). So, the activation of signalling pathway of JAK-STAT is done via IL-12R induction. Several investigations indicate that, signals activate related JAK(s) which may lead to phosphorylate the attached STAT molecule(s). Following the phosphorylation process of STAT molecule(s), DNA binding, nuclear movement, and dimerization will happen. It is revealed that not only IL-12 but also the majority of cytokines use JAK-STAT pathway to transmit related signals. A huge amount of signals sent from more than 50 cytokines are transmitted via seven molecules of STAT (STAT6, STAT5b, STAT5a, STAT4, STAT3, STAT2, and STAT1) among mammals. IL-12 is in association with STAT1, STAT3, STAT4, STAT5a and STAT5b. The STAT4 has the most important role in IL-12 signalling pathway. The induction of STAT4 by IL-12 may lead to promotion of IFN- $\gamma$ production. Indeed, IL-12 by triggering the expression of T-bet provides the Th1 responds and IFN- $\gamma$ secretion $[36,71-82]$.

Different studies show the amazing property of plasticity among Th17 cells. This characterization is appeared by some changes within transcription factors genes which produce Foxp3, ROR- $\gamma$-t, and T-bet. Th17 cells are able to be converted into Tregs or other types of Th1 cells and vice versa. This process is mediated by the transcription factor of ROR- $\gamma$-t which is known as an important regulator agent in association with Th17 cells. Th17 cells have positive influences on Th1 cells differentiation through IL-17 secretion. The IL-17 affects directly on DCs, which results in IL-12 upregulation. This process is applied regarding to intracellular bacterial agents like $F$. tularensis (the causative agent of tularaemia). The activation of STAT4 molecule by IL-12 may lead to generation of Th1 cells. The increase of Th1 cells results in considerable secretion of IFN- $\gamma$. An increase in Th1 secretions can cause inflammation symptoms within a wide range of autoimmune diseases. On the other hand, Th1 cells have antagonistic manner against Th17 cells which may lead to suppression of these cells. The IL-12 plays a key role for polarizing and stabilizing Th1 phenotype against intracellular pathogenic infectious agents and the related autoimmune diseases $[12,34,41,69,82-87]$.

\section{IL-23 and general characteristics}

Ten years after identification of IL-12, IL-23 as the second member of IL-12 family was identified in 2003. Resembling to IL-12, IL-23 is a cytokine that mediates pro-inflammatory mechanism. IL-23 is composed of two subunits including IL-23p40 (as the same in IL-12) and IL-23p19. The co-production of both subunits involving IL-23p40 and IL-23p19 within a same cell and at the same 
time leads to appearance of disulfide bonds between the subunits and the start of normal bioactivity of IL-23 (Fig. 2). There is a 40 percentage similarity between IL-23p19 and IL-12p35 sequences [38, 39, 88-91].

The main IL-23 secreting cells are recognized as activated skin and mucosa membranes APCs such as B cells, endothelial cells, MФs, monocytes and DCs against pathogenic microorganisms. The main known key roles for IL-23 are: triggering IL-17 (responsible for bone erosion and tissue malignancies) via Th17 cells, IL-22, and the development of memory T cells. Secretion of IFN- $\gamma$ (by T cells and NK cells), and differentiation of Th1 with low rates are known as circumstantial role for IL-23. The intensive communication between CD40 and CD40L, may lead to increase the production of IL-23, induction of IL-23R expression, and a positive circular circumstance for promoting IL-23 production. Fungal elements trigger for IL-23 secretion which this occurrence causes differentiation among Th17 cells [35, 92-99].

Recent researches indicate that, the presence of IL-23 guarantees the secretion and survival of Th17 cells [32].

\section{IL-23 and pathogenic microorganisms}

Similar to IL-12, stimulation of TLR2, TLR3, TLR4 and TLR8 via pathogenic microbial ligands triggers the simultaneous secretion of IL-23p40 and IL-23p19. The stimulation of TLR2 via Gram positive bacteria peptidoglycan is significantly more effective than TLR4 via Gram negative bacteria LPS for expression of IL-23p19 and secretion of IL-23. The virulence factor of pertussis toxin produced by Bordetella pertussis promotes the secretion of IL-23. Many studies indicate that the both forms of dimorphic opportunistic fungus of $C$. albicans including yeasts and hyphae trigger the secretion of IL-23 via stimulation of Dectin-1, TLR4, and TLR2 (by yeast) or TLR2 and Dectin-2 (by hyphae) [68, 87, 100-104].

It is revealed that, microbial components and threatening signals within the human body stimulate the secretion of IL-23 throughout the exposed MФs, monocytes, and DCs in a few hours. In consequence, IL-17 is produced and other cells are activated in a cascade pathway which finally may lead to pro-inflammation within infected or wounded anatomical site. The chronic bowel inflammation of Crohn's disease (CD) is an autoimmune disorder in association with IL-23. Thus, IL-12 and IL-23 are recognized as acute protectors for immune system surveillance. Besides, the importance of IL-23 is identified during lung infections caused by Mycobacteria, K. pneumoniae, candidemia caused by C. albicans, and salmonellosis caused by Salmonella. The axes of IL-23-IFN- $\gamma$ and IL-23-IL-17 
are the most effective pathways against extracellular opportunistic pathogenic microorganisms such as C. albicans (causative agent of different types of candidiasis), Pseudomonas aeruginosa (causative agent of wounds and urinary tract infections (UTIs), etc.), Escherichia coli (causative agent of different infections like UTIs) K. pneumoniae (causative agent of lungs, wounds and UT infections) and etc. [34, 38, 63, 64, 87, 105-113].

Furthermore, recent researches reveal that the colonization of normal flora and useful intestinal microbiota in human alimentary tract prevents the attachment of pathogenic microorganisms and balances the immunological responses. The intestinal microbiota increases production of IL-23 which may lead to induce Th17 cells for secreting IL-17. Therefore, the presence of commensal bacteria protects intestinal milieu against pathogenic microbial agents throughout IL-23/ Th17 axis. Interestingly, the high increase of Th17 cells within intestines triggers epithelial cells to produce IL-25. IL-25, reduces IL-23 secretion, downregulates the expansion of Th17 cells and rebalances the intestinal homeostasis $[95,114$, 115].

Investigations show that microbial productions are the major triggering factors which may lead to secret IL-12 and IL-23 via immunological innate cells system. IL-12 prevents the production of IL-23 [47, 50, 116].

Previous investigations indicate that, IL-23 is not necessary for differentiating Th17 cells. However, the presence of IL-23 is vital for polarization and stabilization of Th17 cells which leads to appearance of inflammation symptoms in different types of autoimmune diseases comprising psoriasis, multiple sclerosis, rheumatoid arthritis, CD, and Experimental autoimmune encephalomyelitis (EAE) etc. Not only IL-23, but also IL-12 has a strong inflammatory effect on autoimmune diseases with different pathways [12, 39, 69, 83, 84, 87, 89, 117, 118].

\section{IL-23 receptors and signalling pathway}

IL-23 possesses a bi-subunit receptor consisted of IL-12R- $\beta 1$ (pairing with IL-23p40) and IL-23R (matching with IL-23p19). The presence of all subunits regarding to IL-23 and its receptor guarantees the occurrence of high affinity bonds. The biological effects of IL-23 are performed via heterodimeric signalling pathways of JAK2, STAT3, STAT4, and TYK2 (Fig. 2). Surveys show that IL-6 and IL-21 are the main cytokines which control the regulation of IL-23R [4, 88, $89,118,119]$.

After linking between IL-23 subunits including IL-23p40 and IL-23p19 and their receptors, the STAT3 and STAT4 will be activated (Fig. 2). In parallel with polarization of Th17 cells, IL-23 supports the promotion of heterodimeriza- 
tion of STAT3 and STAT4. Active STAT3 molecules increase the production of cytokines regarding to inflammatory activity. Moreover, STAT3 heterodimers trigger the inflammatory related subset of T cells, Th17. STAT3 is directly affects the process of Th17 differentiation [77, 78, 120].

\section{IL-27 and general characteristics}

The heterodimeric IL-27 is consisted of two subunits including IL-27p28 and Epstein-Barr virus induced gene 3 (EBi3). The EBi3 which resembles IL12 p40 is a glycoprotein with a molecular weight of $34 \mathrm{kDa}$. The IL-27p28 subunit is a helical peptide with a molecular weight of $24.5 \mathrm{kDa}$. Different surveys show that, each subunit is secreted separately and the links between EBi3 and IL-27p28 are unstable because of the lack of sulphide bonds. Interestingly, EBi subunit is able to connect with IL-12p35 to create IL-35 (Fig. 2) [121-124].

APCs (such as DCs, and MФs) are the main resources that secrete IL-27. Two functional key roles including inhibitory and pre-stimulatory have recognized for IL-27. IL-27 is able to inhibit the process of immune system responses (in both sections of innate and adaptive immunities) and to limit the progression of inflammatory. Previous investigations indicate that IL-27 operates as a functional antagonist cytokine to suppress $\mathrm{T}$ cells activities and responses. The suppressive functional effects of IL-27 on MФs and neutrophils are identified in infectious sepsis. Cooperation of IL-27 and IL-12 may lead to trigger mast cells, monocytes, NK and T cells to secrete the IFN- $\gamma$. IFN- $\gamma$ stimulates the production of IL-27 in a positive feedback loop which may lead to suppress the inflammatory responses. Moreover, the presence of IL-2 together with IL-27 prevents the proliferation of Th2, Th17 cells and production of IL-12 and IL-23. On the other hand, the upregulation of T-bet and intracellular adhesion molecule-1 (ICAM-1) gives IL-27 permission for promoting the process of Th1 differentiation. IL-27 in the presence of TGF- $\beta$ is able to produce Type 1 regulatory T (Treg1) cells that secrete anti-inflammatory IL-10. However, for differentiation of Th1 and secretion of IFN- $\gamma$, IL-27 plays its pro-inflammatory role [122, 123, 125-127].

\section{IL-27 and pathogenic microorganisms}

The anti-inflammatory characteristic of IL-27 leads to downregulation of inflammatory process in the meanwhile of acute and chronic infections. The induction of IL-10 and direct suppression of Th1, Th2 and Th17 by IL-27, subverts the efficacy of immune responses for the most; in contrast, the presence of anti- 
IL-27R and IL-12 upregulates the pro-inflammatory responses throughout different cytokines such as IL-18, IFN- $\gamma$ and tumour necrosis factor- $\alpha$ (TNF- $\alpha$ ). These mechanisms are studies on Mycobacterium tuberculosis, Leishmania major, L. donovani, Toxoplasma gondii, Plasmodium berghei, and Trypanosoma cruzi. Thus, IL-27 creates a critical condition during infectious diseases for the host immune system by preventing secretion of IL-2, IL-6, and IL-17 and subverting immune responses against microbial pathogens. The inhibition of IL-2 production may happen via suppressor of cytokine signalling 3 (SOCS3) [123, 128-132].

\section{IL-27 receptors and signalling pathway}

Similar to IL-12 and IL-23, IL-27 has receptor of IL-27R which is composed of a gp130 subunit and a WSX-1 subunit. The latter belongs to the class I cytokine receptor family (TCCR) (Fig. 2). B (activated) cells, DCs, Endothelial (activated) cells, mast cells, monocytes, naïve T cells, and NK cells are all recognized as the IL-27R producer cells. The IL-27 JAK-STAT signalling pathway varies in different immune cells including mast cells (STAT3), monocytes (NF$\kappa \mathrm{B}$, STAT1, and STAT3), naïve T cells (TYK2, JAK1, JAK2, STAT1, STAT2, STAT3, STAT4, STAT5a, and STAT5b) and NK cells (JAK1, STAT1, STAT3, STAT5a, and STAT5b). STAT1 and STAT3 molecules are needed for IL-27 biological activities [123, 133-139].

\section{IL-35 and general characteristics}

The heterodimeric cytokine of IL-35 involves two subunits of p35 and Ebi3 which are also seen in IL-12 and IL-27 (Fig. 2). IL-35 is the newest member of IL-12 family. IL-12 and IL-23 are pro-inflammatory cytokines, while IL-27 has anti-inflammatory activities for the most. However, there are some activities (such as Th1 promotion and IFN- $\gamma$ secretion) which are performed by IL- 27 . In the case of IL-35, this cytokine is recognized as a definite immunosuppressor with a huge potent of suppression. T cells (Th1, Th17) are suppressed via cell cycle termination in G1 phase. No apoptosis feature is used within T cell suppression process. Prior to APCs, nTregs are the main resources for IL-35 secretion. IL-35 resembling IL-10 and TGF- $\beta$, has the capability of triggering proliferation of the iTreg of iTr35 (the CD4 ${ }^{+}$Tregs induced by IL-35). iTr35 produces IL-10, Foxp3, and TGF- $\beta$; but suppresses via IL-35. nTregs are able to transform the suppressed $\mathrm{T}$ cells into iTr35. The contribution of $i \operatorname{Tr} 35$ for regulating the envi- 
ronmental parameters regarding to inflammation is identified. Moreover, the entrance of IL-35 into the inflammatory sites at the present of nTreg works for the maximal potential $[8,12,13,28]$.

\section{IL-35 and pathogenic microorganisms}

Immune cells of monocytes which are activated by bacterial LPS and proinflammatory cytokines are able to transcribe IL-35 genes [9]. More investigations are needed relating to IL-35 activities against microbial pathogens.

\section{IL-35 receptors and signalling pathway}

Unlike other members of IL-12 family, IL-35 encompasses four receptors including IL-12R- $\beta 2-I L-27 R$ (WSX-1), IL-12R- $\beta 2-I L-12 R-\beta 2$, IL-12R- $\beta 2$-gp130, and gp130-gp130. Normally, IL-12R- $\beta 2$ subunit is produced within active NK and T cells; while gp130 is secreted by the majority of immune cells. The IL-35 signalling pathway is consisted of JAK1, JAK2, STAT1, STAT3, and STAT4 molecules (Fig. 2). A group of B cells such as regulatory B cells which produce IL-35 possesses two receptor subunits of IL-12R- $\beta 2$ and IL-27R- $\alpha$ for IL-35 for activating STAT1 and STAT3 molecules. This characteristic indicates the probable contribution of regulatory B cells in association with immune system responses in healthy people and patients. In T cells, the IL-35 signals encompass three receptor subunits comprising IL-12R- $\beta 2-I L-12 R-\beta 2$, IL-12R- $\beta 2-g p 130$, and gp130-gp130 which activate STAT1 and STAT4 molecules [23, 28, 75, 140, 141].

\section{The connection of IL-12 family with IL-6 family}

In addition to IL-12 cytokines, the IL- 6 cytokine family belongs to type-I cytokines. The IL-12 family members excluding IL-35 (IL-35 is secreted by Tregs and some of Bregs) are secreted by APCs (DCs, monocytes, and MФs), whereas the IL-6 cytokines are produced by a vast range of cells including adipocytes, B cells, endothelial cell, fibroblasts, keratinocytes, mesangial cells, monocytes and $\mathrm{T}$ cells. These families have some similarities and dissimilarities regarding to their structural and molecular properties. The IL-12 and IL-6 superfamilies encompass similar structural motifs of four-helix-bundle and hematopoietin receptor domain. On the other hand, the IL-6 family members including 
cardiotrophin-1 (CT-1), cardiotrophin like cytokine (CLC), ciliary neurotrophic factor (CNTF), IL-6, IL-11, leukaemia inhibitory factor (LIF), neuropoietin (NP), and oncostatin M (OSM) are single-structured monomers while the IL-12 cytokines possess a heterodimeric structure of $\alpha-\beta$-subunits (Table I). Furthermore, the cytokines biological activities are performed via their specific receptors. In this article we just focus on IL-6 and its receptors [31, 94, 122, 142-146].

The IL-6 receptors comprising (IL-6R/IL-6R- $\alpha / \mathrm{gp} 80 / \mathrm{CD} 126$ ) and gp130 (IL-6R- $\beta / C D 130$ ) molecules have a key role in association with IL-6 biological tasks. The hexamer complex of IL-6-IL-6R- $\alpha$-gp130 (including six molecules/ two molecules per each) creates powerful signals within cells. The evolutionary scientific documents show that IL-12 cytokines $\beta$-subunits including p40 and Ebi3 have close relationship with IL-6R- $\alpha$ while a close homology is observed between gp130 and the both components of IL-12 receptors (IL-12R- $\beta 1$ and $12 \mathrm{R}-\beta 2$ ), (Table I and Fig. 2). The gp130 molecule is present in receptors of IL-27 (gp130 and WSX1) and IL-6 (gp130 and IL-6R- $\alpha$ ). The glycoprotein of gp130, is the main signal transducer in association with IL-6 and IL-27 signalling pathways. Interestingly, the signalling pathway of IL-6 includes JAK1, JAK2, TYK2, STAT1, and STAT3. Moreover it is remarkable finding that, the IL-6 as well as IL-11 applies for gp130-gp130 homodimer-structures in its signalling pathway $[31,79,94,143,144,147,148]$.

According to the previous studies, the $40-\mathrm{kDa}$ molecule of p40 (IL-12- $\beta$ subunit and IL-23- $\beta$-subunit) is able to build homodimer structures of (p40)2 which have antagonistic functional properties against IL-12 and IL-23. The (p40)2 homodimers have a strong affinity for IL-12R- $\beta 1$-subunits. The new iden-

Table I. A structural comparison between IL-6 and IL-12 family cytokines

\begin{tabular}{ccccc}
\hline $\begin{array}{c}\text { Cytokine } \\
\text { family }\end{array}$ & Cytokines & Structure & $\alpha$-Subunit & $\beta$-Subunit \\
\hline IL-6 & $\begin{array}{c}\text { cardiotrophin-1 (CT-1), } \\
\text { cardiotrophin like cytokine (CLC), } \\
\text { ciliary neurotrophic factor (CNTF), } \\
\text { granulocyte colony stimulating factor } \\
\text { (GCSF), IL-6, IL-11, } \\
\text { leukaemia inhibitory factor (LIF), } \\
\text { neuropoietin (NP), oncostatin M (OSM) }\end{array}$ & monomer & $\begin{array}{c}\text { Homologous to } \\
\text { IL-12 cytokines } \\
\alpha \text {-subunits }\end{array}$ & $\begin{array}{c}\text { No } \\
\text { homology }\end{array}$ \\
\hline IL-12 & IL-12 & heterodimer & p35 & \\
& IL-23 & p19 & p40 \\
& IL-27 & p28 & Ebi3 \\
& IL-35 & p35 & Ebi3 \\
\hline
\end{tabular}


tified homologies among IL-6 and IL-12 family members and the related receptors have shown that, the gp130 as a receptor is able to contribute to inhibit the formation of (p40)2 homodimers through its high homology with IL-12R- $\beta 1$ and IL-12R- $\beta 2$. Moreover, the IL-23 receptors include IL-12R- $\beta 1$ and IL-23R; the IL-23R has a close similarity with gp130. These characteristics may decrease the formation of (p40)2 homodimers [31, 47, 141, 147, 149, 150].

\section{Conclusion}

Recent investigations reveal similarities and dissimilarities among functions, structures, regulatory systems, and secretion pathways of IL-12 family members. The importance of IL-12 family is considerable in different fields such as gene therapy, cancer therapy, tumour therapy, and vaccination. Thus, the science of bioengineering is trying to use IL-12 family members as especial therapeutic tools in modern pharmacology. Besides, the members of IL-12 family are known as important biomarkers in association with infections, autoimmune diseases, and cancers.

Furthermore, the progression of advanced molecular diagnostic technology of microarray provides an appropriate opportunity for applying IL-12 family members as brilliant diagnostic playmakers in the field of infectious diseases with high accuracy, reliability, and reproducibility.

The recent decade has given us the opportunity for identifying this group of cytokines. Identification of cytokines, their receptors and signalling pathway permit us to have a much better diagnostic approach and designing definite therapeutic methods. The results from different studies confirm a variety of mechanisms in different infections. So, an individual pathway and mechanism can be used as a prompt sign for performing an accurate diagnosis and definite treatment. We conclude that, the ability of IL-12 family cytokines as significant immunological playmakers together with microarray technology can provide us a new chapter of reliable diagnostics and successful treatments now and tomorrow.

\section{Conflict of Interest}

The authors declare that there is no conflict of interests regarding the publication of this paper. 


\section{References}

1. Behzadi, P., Behzadi, E.: Word Mapping in Biology, Medicine \& Microbiology, 1st Edition. Persian Science \& Research Publisher, Tehran, 2012, pp. 38, 50.

2. Dinarello, C. A.: Proinflammatory cytokines. Chest Journal 118, 503-508 (2000).

3. Yuzhalin, A. E., Kutikhin, A. G.: Interleukin-12: clinical usage and molecular markers of cancer susceptibility. Growth Factors 30, 176-191 (2012). DOI: 10.3109/08977194.2012. 678843

4. Belladonna, M. L., Grohmann, U.: Bioengineering heterodimeric cytokines: turning promiscuous proteins into therapeutic agents. Biotechnol Genet Eng Rev 29, 149-174 (2013). DOI: 10.1080/02648725.2013.801228

5. Belladonna, M. L., Renauld, J. C., Bianchi, R., Vacca, C., Fallarino, F., Orabona, C., Fioretti, M. C., Grohmann, U., Puccetti, P.: IL-23 and IL-12 have overlapping, but distinct, effects on murine dendritic cells. J Immunol 168, 5448-5454 (2002).

6. Behzadi, P., Behzadi E.: Detection of apoptosis feature in ultraviolet light-exposed Trichophyton rubrum. Turkiye Klinikleri J Med Sci 26, 607-610 (2006).

7. Behzadi, P., Ranjbar, R.: Caspases and apoptosis. MEDT 1, 1-4 (2015).

8. Vignali, D. A., Kuchroo, V. K.: IL-12 family cytokines: immunological playmakers. Nat Immunol 13, 722-728 (2012). DOI: 10.1038/ni.2366

9. Banchereau, J., Pascual, V., O'Garra, A.: From IL-2 to IL-37: the expanding spectrum of anti-inflammatory cytokines. Nat Immunol 13, 925-931 (2012). DOI: 10.1038/ni.2406

10. Honda, K., Littman, D. R.: The microbiome in infectious disease and inflammation. Annu Rev Immunol 30, 759-795 (2012). DOI: 10.1146/annurev-immunol-020711-074937

11. Lee, Y. K., Mazmanian, S. K.: Has the microbiota played a critical role in the evolution of the adaptive immune system? Science 330, 1768-1773 (2010). DOI: 10.1126/science. 1195568

12. Hamza, T., Barnett, J. B., Li, B.: Interleukin 12 a key immunoregulatory cytokine in infection applications. Int J Mol Sci 11, 789-806 (2010). DOI: 10.3390/ijms11030789

13. Sun, L., He, C., Nair, L., Yeung, J., Egwuagu, C. E.: Interleukin 12 (IL-12) family cytokines: role in immune pathogenesis and treatment of CNS autoimmune disease. Cytokine 75, 249-255 (2015). DOI: 10.1016/j.cyto.2015.01.030

14. Hao, S., Baltimore, D.: The stability of mRNA influences the temporal order of the induction of genes encoding inflammatory molecules. Nat Immunol 10, 281-288 (2009). DOI: $10.1038 /$ ni.1699

15. Anderson, P.: Post-transcriptional regulons coordinate the initiation and resolution of inflammation. Nat Rev Immunol 10, 24-35 (2010). DOI: 10.1038/nri2685

16. Anderson, P.: Post-transcriptional control of cytokine production. Nat Immunol 9, 353 359 (2008). DOI: 10.1038/nil584

17. Keene, J. D.: RNA regulons: coordination of post-transcriptional events. Nat Rev Genet 8, 533-543 (2007). DOI: 10.1038/nrg2111

18. Stoecklin, G., Anderson, P.: Posttranscriptional mechanisms regulating the inflammatory response. Adv Immunol 89, 1-37 (2006). DOI: 10.1016/S0065-2776(05)89001-7

19. Hamilton, T. A., Novotny, M., Datta, S., Mandal, P., Hartupee, J., Tebo, J., Li, X.: Chemokine and chemoattractant receptor expression: post-transcriptional regulation. J Leukoc Biol 82, 213-219 (2007). DOI: 10.1189/jlb.1206754 
20. Hamilton, T. A., Ohmori, Y., Tebo, J.: Regulation of chemokine expression by antiinflammatory cytokines. Immunol Res 25, 229-245 (2002). DOI: 10.1385/IR:25:3:229

21. Behzadi, P., Ranjbar, R., Alavian, S. M.: Nucleic acid-based approaches for detection of viral hepatitis. Jundishapur J Microbiol 8, el7449 (2015). DOI: 10.5812/jjm.17449

22. Behzadi, P., Behzadi, E., Ranjbar, R.: Microarray probe set: biology, bioinformatics and biophysics. Alban Med J 2, 78-83 (2015).

23. Wang, R.-X., Yu, C.-R., Dambuza, I. M., Mahdi, R. M., Dolinska, M. B., Sergeev, Y. V., Wingfield, P. T., Kim, S.-H., Egwuagu, C. E.: Interleukin-35 induces regulatory B cells that suppress autoimmune disease. Nat Med 20, 633-641 (2014). DOI: 10.1038/nm.3554

24. Shen, P., Roch, T., Lampropoulou, V., O'Connor, R. A., Stervbo, U., Hilgenberg, E., Ries, S., Jaimes, Y., Daridon, C., Li, R.: IL-35-producing B cells are critical regulators of immunity during autoimmune and infectious diseases. Nature 507, 366-370 (2014). DOI: $10.1038 /$ nature12979

25. Steinman, R. M.: Linking innate to adaptive immunity through dendritic cells. Novartis 790, 101-109 (2006).

26. Beadling, C., Slifka, M. K.: Regulation of innate and adaptive immune responses by the related cytokines IL-12, IL-23, and IL-27. Arch Immunol Ther Exp 54, 15-24 (2006). DOI: $10.1007 / \mathrm{s} 00005-006-0002-6$

27. Collison, L. W., Workman, C. J., Kuo, T. T., Boyd, K., Wang, Y., Vignali, K. M., Cross, R., Sehy, D., Blumberg, R. S., Vignali, D. A.: The inhibitory cytokine IL-35 contributes to regulatory T-cell function. Nature 450, 566-569 (2007). DOI: 10.1038/nature06306

28. Olson, B. M., Sullivan, J. A., Burlingham, W. J.: Interleukin 35: a key mediator of suppression and the propagation of infectious tolerance. Front Immunol 4, (2013). DOI: 10.3389/fimmu.2013.00315

29. Chang, A. Y., Bhattacharya, N.: Learning to live together: harnessing regulatory $\mathrm{T}$ cells to induce organ transplant tolerance. Yale J Biol Med 84, 345 (2011).

30. Collison, L. W., Chaturvedi, V., Henderson, A. L., Giacomin, P. R., Guy, C., Bankoti, J., Finkelstein, D., Forbes, K., Workman, C. J., Brown, S. A.: IL-35-mediated induction of a potent regulatory T cell population. Nat Immunol 11, 1093-1101 (2010). DOI: 10.1038/ ni. 1952

31. Jones, L. L., Vignali, D. A.: Molecular interactions within the IL-6/IL-12 cytokine/receptor superfamily. Immunol Res 51, 5-14 (2011). DOI: 10.1007/s12026-011-8209-y

32. Shimizu, J., Kaneko, F., Suzuki, N.: Skewed helper T-cell responses to IL-12 family cytokines produced by antigen-presenting cells and the genetic background in Behcet's disease. Genet Res Int 2013, 11 (2013). DOI: http://dx.doi.org/10.1155/2013/363859

33. Gee, K., Guzzo, C., Mat, C., Nor, F., Ma, W., Kumar, A.: The IL-12 family of cytokines in infection, inflammation and autoimmune disorders. Inflamm Allergy Drug Targets 8, 40-52 (2009). DOI: http://dx.doi.org/10.2174/187152809787582507

34. Bettelli, E., Korn, T., Kuchroo, V. K.: Th17: the third member of the effector T cell trilogy. Curr Opin Immunol 19, 652-657 (2007). DOI: 10.1016/j.coi.2007.07.020

35. Gaffen, S. L., Jain, R., Garg, A. V., Cua, D. J.: The IL-23-IL-17 immune axis: from mechanisms to therapeutic testing. Nat Rev Immunol 14, 585-600 (2014). DOI: 10.1038/ nri3707

36. Collison, L. W., Vignali, D. A.: Interleukin-35: odd one out or part of the family? Immunol Rev 226, 248-262 (2008). DOI: 10.1111/j.1600-065X.2008.00704.x 
37. Lasek, W., Zagożdżon, R., Jakobisiak, M.: Interleukin 12: still a promising candidate for tumor immunotherapy? Cancer Immunol Immunother 63, 419-435 (2014). DOI: 10.1007/ s00262-014-1523-1

38. Kastelein, R. A., Hunter, C. A., Cua, D. J.: Discovery and biology of IL-23 and IL-27: related but functionally distinct regulators of inflammation. Annu Rev Immunol 25, 221-242 (2007). DOI: 10.1146/annurev.immunol.22.012703.104758

39. Oppmann, B., Lesley, R., Blom, B., Timans, J. C., Xu, Y., Hunte, B., Vega, F., Yu, N., Wang, J., Singh, K.: Novel p19 protein engages IL-12p40 to form a cytokine, IL-23, with biological activities similar as well as distinct from IL-12. Immunity 13, 715-725 (2000). DOI: $10.1016 / \mathrm{S} 1074-7613(00) 00070-4$

40. Jalah, R., Rosati, M., Ganneru, B., Pilkington, G. R., Valentin, A., Kulkarni, V., Bergamaschi, C., Chowdhury, B., Zhang, G.-M., Beach, R. K.: The p40 subunit of interleukin (IL)-12 promotes stabilization and export of the p35 subunit implications for improved IL-12 cytokine production. J Biol Chem 288, 6763-6776 (2013). DOI: 10.1074/ jbc.M112.436675

41. Watford, W. T., Moriguchi, M., Morinobu, A., O’Shea, J. J.: The biology of IL-12: coordinating innate and adaptive immune responses. Cytokine Growth Factor Rev 14, 361368 (2003). DOI: 10.1016/S1359-6101(03)00043-1

42. Goriely, S., Neurath, M. F., Goldman, M.: How microorganisms tip the balance between interleukin-12 family members. Nat Rev Immunol 8, 81-86 (2008). DOI: 10.1038/ nri2225

43. Takaoka, A., Yanai, H., Kondo, S., Duncan, G., Negishi, H., Mizutani, T., Kano, S. I., Honda, K., Ohba, Y., Mak, T. W.: Integral role of IRF-5 in the gene induction programme activated by Toll-like receptors. Nature 434, 243-249 (2005). DOI: 10.1038/nature03308

44. Ouyang, X., Negishi, H., Takeda, R., Fujita, Y., Taniguchi, T., Honda, K.: Cooperation between MyD88 and TRIF pathways in TLR synergy via IRF5 activation. Biochem Biophys Res Commun 354, 1045-1051 (2007). DOI: 10.1016/j.bbrc.2007.01.090

45. Weinmann, A. S., Mitchell, D. M., Sanjabi, S., Bradley, M. N., Hoffmann, A., Liou, H. C., Smale, S. T.: Nucleosome remodeling at the IL-12 p40 promoter is a TLR-dependent, Rel-independent event. Nat Immunol 2, 51-57 (2001). DOI: 10.1038/83168

46. Murphy, T. L., Cleveland, M. G., Kulesza, P., Magram, J., Murphy, K. M.: Regulation of interleukin 12 p40 expression through an NF-kappa B half-site. Mol Cell Biol 15, 5258-5267 (1995). DOI: 10.1128/MCB.15.10.5258

47. Lyakh, L., Trinchieri, G., Provezza, L., Carra, G., Gerosa, F.: Regulation of interleukin-12/interleukin-23 production and the T-helper 17 response in humans. Immunol Rev 226, 112-131 (2008). DOI: 10.1111/j.1600-065X.2008.00700.x

48. Carra, G., Gerosa, F., Trinchieri, G.: Biosynthesis and posttranslational regulation of human IL-12. The Journal of Immunology 164, 4752-4761 (2000). DOI: 10.4049/jimmunol.164.9.4752

49. Murphy, F. J., Hayes, M. P., Burd, P. R.: Disparate intracellular processing of human IL-12 preprotein subunits: atypical processing of the P35 signal peptide. J Immunol 164, 839-847 (2000). DOI: 10.4049/jimmunol.164.2.839

50. Gerosa, F., Baldani-Guerra, B., Lyakh, L. A., Batoni, G., Esin, S., Winkler-Pickett, R. T., Consolaro, M. R., De Marchi, M., Giachino, D., Robbiano, A.: Differential regulation of interleukin 12 and interleukin 23 production in human dendritic cells. JEM 205, 14471461 (2008). DOI: $10.1084 /$ jem.20071450 
51. Cleveland, M. G., Gorham, J. D., Murphy, T. L., Tuomanen, E., Murphy, K. M.: Lipoteichoic acid preparations of Gram-positive bacteria induce interleukin-12 through a CD14-dependent pathway. Infect Immun 64, 1906-1912 (1996).

52. Gautier, G., Humbert, M., Deauvieau, F., Scuiller, M., Hiscott, J., Bates, E. E., Trinieri, G., Caux, C., Garrone, P.: A type I interferon autocrine-paracrine loop is involved in Toll-like receptor-induced interleukin-12p70 secretion by dendritic cells. JEM 201, 1435-1446 (2005). DOI: 10.1084/jem.20041964

53. Croxford, A. L., Kulig, P., Becher, B.: IL-12-and IL-23 in health and disease. Cytokine Growth Factor Rev 25, 415-421 (2014). DOI: 10.1016/j.cytogfr.2014.07.017

54. Grohmann, U., Belladonna, M. L., Bianchi, R., Orabona, C., Ayroldi, E., Fioretti, M. C., Puccetti, P.: IL-12 acts directly on DC to promote nuclear localization of NF- $\kappa \mathrm{B}$ and primes DC for IL-12 production. Immunity 9, 315-323 (1998). DOI: 10.1016/S10747613(00)80614-7

55. Aste-Amezaga, M., Ma, X., Sartori, A., Trinchieri, G.: Molecular mechanisms of the induction of IL-12 and its inhibition by IL-10. J Immunol 160, 5936-5944 (1998).

56. Segal, B. M., Dwyer, B. K., Shevach, E. M.: An interleukin (IL)-10/IL-12 immunoregulatory circuit controls susceptibility to autoimmune disease. JEM 187, 537-546 (1998). DOI: $10.1084 /$ jem.187.4.537

57. Medzhitov, R.: Toll-like receptors and innate immunity. Nat Rev Immunol 1, 135-145 (2001). DOI: $10.1038 / 35100529$

58. Novelli, F., Casanova, J.-L.: The role of IL-12, IL-23 and IFN- $\gamma$ in immunity to viruses. Cytokine Growth Factor Rev 15, 367-377 (2004). DOI: 10.1016/j.cytogfr.2004.03.009

59. Fieschi, C., Casanova, J. L.: Mini-review. The role of interleukin-12 in human infectious diseases: only a faint signature. Eur J Immunol 33, 1461-1464 (2003). DOI: 10.1002/ eji. 200324038

60. Haskó, G., Szabó, C.: IL-12 as a therapeutic target for pharmacological modulation in immune-mediated and inflammatory diseases: regulation of $\mathrm{T}$ helper 1/T helper 2 responses. Br J Pharmacol 127, 1295-1304 (1999). DOI: 10.1038/sj.bjp.0702689

61. Ashman, R. B., Vijayan, D., Wells, C. A.: IL-12 and related cytokines: function and regulatory implications in Candida albicans infection. Clin Dev Immunol 2011, (2010). DOI: $10.1155 / 2011 / 686597$

62. O'Garra, A., Murphy, K. M.: From IL-10 to IL-12: how pathogens and their products stimulate APCs to induce TH1 development. Nat Immunol 10, 929-932 (2009). DOI: 10.1038/ni0909-929

63. Happel, K. I., Dubin, P. J., Zheng, M., Ghilardi, N., Lockhart, C., Quinton, L. J., Odden, A. R., Shellito, J. E., Bagby, G. J., Nelson, S.: Divergent roles of IL-23 and IL-12 in host defense against Klebsiella pneumoniae. JEM 202, 761-769 (2005). DOI: 10.1084/ jem.20050193

64. MacLennan, C., Fieschi, C., Lammas, D. A., Picard, C., Dorman, S. E., Sanal, O., MacLennan, J. M., Holland, S. M., Ottenhoff, T. H., Casanova, J.-L.: Interleukin (IL)-12 and IL-23 are key cytokines for immunity against Salmonella in humans. J Infect Dis 190, 1755-1757 (2004). DOI: 10.1086/425021

65. Goriely, S., Goldman, M.: Interleukin-12 family members and the balance between rejection and tolerance. Curr Opin Organ Transplant 13, 4-9 (2008). DOI: 10.1097/ MOT.0b013e3282f406c4

66. Janßen, M.: Influence of IL-12 cytokine family members on T cell differentiation in experimental cerebral malaria. Hamburg, Universität Hamburg, Diss., 2012. 
67. Dufour, J.-F., Clavien, P.-A., Graf, R., Trautwein, C.: Signaling pathways in liver diseases, 2nd Edition DOI: 10.1007/978-3-642-00150-5, Springer, 2010, pp.

68. Re, F., Strominger, J. L.: Toll-like receptor 2 (TLR2) and TLR4 differentially activate human dendritic cells. J Biol Chem 276, 37692-37699 (2001). DOI: 10.1074/jbc. M105927200

69. Behzadi P., Ranjbar, R.: Enzymatic pathways of intracellular survival, replication and phagosomal escape of Francisella spp.: a review. MEDT 1, 1-5 (2015).

70. Gately, M. K., Renzetti, L. M., Magram, J., Stern, A. S., Adorini, L., Gubler, U., Presky, D. H.: The interleukin-12/interleukin-12-receptor system: role in normal and pathologic immune responses. Annu Rev Immunol 16, 495-521 (1998). DOI: 10.1146/annurev. immunol.16.1.495

71. Sinigaglia, F., D’Ambrosio, D., Panina-Bordignon, P., Rogge, L.: Regulation of the IL-12/IL-12R axis: a critical step in T-helper cell differentiation and effector function. Immunol Rev 170, 65-72 (1999). DOI: 10.1111/j.1600-065X.1999.tb01329.x

72. Jacobson, N. G., Szabo, S. J., Weber-Nordt, R. M., Zhong, Z., Schreiber, R. D., Darnell, J., Murphy, K. M.: Interleukin 12 signaling in T helper type 1 (Th1) cells involves tyrosine phosphorylation of signal transducer and activator of transcription (Stat) 3 and Stat4. JEM 181, 1755-1762 (1995). DOI: 10.1084/jem.181.5.1755

73. Bacon, C. M., McVicar, D. W., Ortaldo, J. R., Rees, R. C., O’Shea, J., Johnston, J. A.: Interleukin 12 (IL-12) induces tyrosine phosphorylation of JAK2 and TYK2: differential use of Janus family tyrosine kinases by IL-2 and IL-12. JEM 181, 399-404 (1995). DOI: $10.1084 /$ jem.181.1.399

74. Bacon, C. M., Petricoin, E. F., Ortaldo, J. R., Rees, R. C., Larner, A. C., Johnston, J. A., O'Shea, J. J.: Interleukin 12 induces tyrosine phosphorylation and activation of STAT4 in human lymphocytes. Proc Natl Acad Sci 92, 7307-7311 (1995).

75. Presky, D. H., Yang, H., Minetti, L. J., Chua, A. O., Nabavi, N., Wu, C.-Y., Gately, M. K., Gubler, U.: A functional interleukin 12 receptor complex is composed of two $\beta$-type cytokine receptor subunits. Proc Natl Acad Sci 93, 14002-14007 (1996).

76. Del Vecchio, M., Bajetta, E., Canova, S., Lotze, M. T., Wesa, A., Parmiani, G., Anichini, A.: Interleukin-12: biological properties and clinical application. Clin Cancer Res 13, 4677-4685 (2007). DOI: 10.1158/1078-0432.CCR-07-0776

77. Delgoffe, G. M., Vignali, D. A.: STAT heterodimers in immunity: a mixed message or a unique signal? JAKSTAT 2(1):e23060. DOI: 10.4161/jkst.23060

78. Villarino, A. V., Kanno, Y., Ferdinand, J. R., O'Shea, J. J.: Mechanisms of Jak/STAT signaling in immunity and disease. J Immunol 194, 21-27 (2015). DOI: 10.4049/ jimmunol.1401867

79. Trinchieri, G., Pflanz, S., Kastelein, R. A.: The IL-12 family of heterodimeric cytokines: new players in the regulation of T cell responses. Immunity 19, 641-644 (2003). DOI: 10.1016/S1074-7613(03)00296-6

80. Lighvani, A. A., Frucht, D. M., Jankovic, D., Yamane, H., Aliberti, J., Hissong, B. D., Nguyen, B. V., Gadina, M., Sher, A., Paul, W. E.: T-bet is rapidly induced by interferon- $\gamma$ in lymphoid and myeloid cells. Proc Natl Acad Sci 98, 15137-15142 (2001). DOI: 10.1073/ pnas. 261570598

81. Mullen, A. C., High, F. A., Hutchins, A. S., Lee, H. W., Villarino, A. V., Livingston, D. M., Kung, A. L., Cereb, N., Yao, T.-P., Yang, S. Y.: Role of T-bet in commitment of TH1 cells before IL-12-dependent selection. Science 292, 1907-1910 (2001). DOI: 10.1126/ science. 1059835 
82. Trinchieri, G.: Interleukin-12 and the regulation of innate resistance and adaptive immunity. Nat Rev Immunol 3, 133-146 (2003). DOI: 10.1038/nri1001

83. Gaffen, S. L.: Recent advances in the IL-17 cytokine family. Curr Opin Immunol 23, 613-619 (2011). DOI: 10.1016/j.coi.2011.07.006

84. Steinman, L.: A brief history of TH17, the first major revision in the TH1/TH2 hypothesis of T cell-mediated tissue damage. Nat Med 13, 139-145 (2007). DOI: 10.1038/ nm1551

85. McWilliams, I. L., Rajbhandari, R., Nozell, S., Benveniste, E., Harrington, L. E.: STAT4 controls GM-CSF production by both Th1 and Th17 cells during EAE. J Neuroinflammation 12, 128 (2015). DOI: 10.1186/s12974-015-0351-3

86. Good, S. R., Thieu, V. T., Mathur, A. N., Yu, Q., Stritesky, G. L., Yeh, N., O’Malley, J. T., Perumal, N. B., Kaplan, M. H.: Temporal induction pattern of STAT4 target genes defines potential for Th1 lineage-specific programming. J Immunol 183, 3839-3847 (2009). DOI: 10.4049/jimmunol.0901411

87. Alber, G., Al-Robaiy, S., Kleinschek, M., Knauer, J., Krumbholz, P., Richter, J., Schoeneberger, S., Schuetze, N., Schulz, S., Toepfer, K.: Induction of immunity and inflammation by interleukin-12 family members. In (eds): Cytokines as Potential Therapeutic Targets for Inflammatory Skin Diseases, Edition. Springer, 2006, pp. 107-127.

88. Parham, C., Chirica, M., Timans, J., Vaisberg, E., Travis, M., Cheung, J., Pflanz, S., Zhang, R., Singh, K. P., Vega, F.: A receptor for the heterodimeric cytokine IL-23 is composed of IL-12R $\beta 1$ and a novel cytokine receptor subunit, IL-23R. J Immunol 168, 5699-5708 (2002). DOI: 10.4049/jimmunol.168.11.5699

89. Cua, D. J., Sherlock, J., Chen, Y., Murphy, C. A., Joyce, B., Seymour, B., Lucian, L., To, W., Kwan, S., Churakova, T.: Interleukin-23 rather than interleukin-12 is the critical cytokine for autoimmune inflammation of the brain. Nature 421, 744-748 (2003). DOI: 10.1038/nature01355

90. Murphy, C. A., Langrish, C. L., Chen, Y., Blumenschein, W., McClanahan, T., Kastelein, R. A., Sedgwick, J. D., Cua, D. J.: Divergent pro- and antiinflammatory roles for IL-23 and IL-12 in joint autoimmune inflammation. JEM 198, 1951-1957 (2003). DOI: 10.1084/ jem. 20030896

91. Xu, M., Mizoguchi, I., Morishima, N., Chiba, Y., Mizuguchi, J., Yoshimoto, T.: Regulation of antitumor immune responses by the IL-12 family cytokines, IL-12, IL-23, and IL-27. Clin Dev Immunol pii: 832454. (2010) DOI: 10.1155/2010/832454

92. McKenzie, B. S., Kastelein, R. A., Cua, D. J.: Understanding the IL-23-IL-17 immune pathway. Trends Immunol 27, 17-23 (2006). DOI: 10.1016/j.it.2005.10.003

93. Brombacher, F., Kastelein, R. A., Alber, G.: Novel IL-12 family members shed light on the orchestration of Th1 responses. Trends Immunol 24, 207-212 (2003). DOI: 10.1016/ S1471-4906(03)00067-X

94. Hunter, C. A.: New IL-12-family members: IL-23 and IL-27, cytokines with divergent functions. Nat Rev Immunol 5, 521-531 (2005). DOI: 10.1038/nri1648

95. Damsker, J. M., Hansen, A. M., Caspi, R. R.: Th1 and Th17 cells. Ann N Y Acad Sci 1183, 211-221 (2010). DOI: 10.1111/j.1749-6632.2009.05133.x

96. Macatonia, S. E., Hosken, N. A., Litton, M., Vieira, P., Hsieh, C.-S., Culpepper, J. A., Wysocka, M., Trinchieri, G., Murphy, K. M., O’Garra, A.: Dendritic cells produce IL-12 and direct the development of Th1 cells from naive $\mathrm{CD} 4^{+} \mathrm{T}$ cells. J Immunol 154, 50715079 (1995). 
97. Schulz, O., Edwards, A. D., Schito, M., Aliberti, J., Manickasingham, S., Sher, A., e Sousa, C. R.: CD40 triggering of heterodimeric IL-12 p70 production by dendritic cells in vivo requires a microbial priming signal. Immunity 13, 453-462 (2000). DOI: 10.1016/ S1074-7613(00)00045-5

98. Abdi, K., Singh, N., Matzinger, P.: T-cell control of IL-12p75 production. Scand J Immunol 64, 83-92 (2006). DOI: 10.1111/j.1365-3083.2006.01767.x

99. Wei, X.-Q., Rogers, H., Lewis, M. A., Williams, D. W.: The role of the IL-12 cytokine family in directing T-cell responses in oral candidosis. Clin Dev Immunol 2011 (2011): 697340. DOI: $10.1155 / 2011 / 697340$

100. Hemmi, H., Takeuchi, O., Kawai, T., Kaisho, T., Sato, S., Sanjo, H., Matsumoto, M., Hoshino, K., Wagner, H., Takeda, K.: A Toll-like receptor recognizes bacterial DNA. Nature 408, 740-745 (2000). DOI: 10.1038/35047123

101. Napolitani, G., Rinaldi, A., Bertoni, F., Sallusto, F., Lanzavecchia, A.: Selected Toll-like receptor agonist combinations synergistically trigger a $\mathrm{T}$ helper type 1-polarizing program in dendritic cells. Nat Immunol 6, 769-776 (2005). DOI: 10.1038/ni1223

102. Bekeredjian-Ding, I., Roth, S. I., Gilles, S., Giese, T., Ablasser, A., Hornung, V., Endres, S., Hartmann, G.: T cell-independent, TLR-induced IL-12p70 production in primary human monocytes. J Immunol 176, 7438-7446 (2006). DOI: 10.4049/jimmunol.176.12.7438

103. Han, K. H., Choi, S. J., Lee, K. H.: Immunological features of macrophages induced by various morphological structures of Candida albicans. J Microbiol Biotechnol 23, 10311040 (2013). DOI: http://dx.doi.org/10.4014/jmb.1212.12030

104. Fedele, G., Stefanelli, P., Spensieri, F., Fazio, C., Mastrantonio, P., Ausiello, C. M.: Bordetella pertussis-infected human monocyte-derived dendritic cells undergo maturation and induce Th1 polarization and interleukin-23 expression. Infect Immun 73, 1590-1597 (2005). DOI: 10.1128/IAI.73.3.1590-1597.2005

105. Behzadi, P., Behzadi, E., Ranjbar, R.: The incidence and prevalence of Crohn's disease in global scale. SOJ Immunol 3, 1-6 (2015). DOI: http://dx.doi.org/10.15226/soji/3/2/ 00125

106. Behzadi, P., Behzadi, E., Ranjbar, R.: Autoimmunity, Crohn's disease and anti-Saccharomyces cerevisiae autoantibodies. Farmacist.ro 156, 50-52 (2014).

107. Behzadi, P., Behzadi, E.: A study on apoptosis inducing effects of uvb irradiation in Pseudomonas aeruginosa. Roum Arch Microbiol Immunol 70, 30-33 (2011).

108. Behzadi, P., Behzadi, E.: Evaluation of uvb light efficacy for inducing apoptosis in Candida albicans cultures. Roum Arch Microbiol Immunol 71, 39-42 (2012).

109. Behzadi, P., Behzadi, E., Ranjbar, R.: Urinary tract infections and Candida albicans. CEJU 68, 96-101 (2015). DOI: 10.5173/ceju.2015.01.474

110. Jahandeh, N., Ranjbar, R., Behzadi, P., Behzadi, E.: Uropathogenic Escherichia coli virulence genes: invaluable approaches for DNA microarray probe designing. CEJU 68 , 452-458 (2015). DOI: 10.5173/ceju.2015.625

111. Behzadi, P., Behzadi, E., Ranjbar, R.: Pediatric oral thrush. Pediatru.ro 34, 36-39 (2014).

112. Behzadi, P., Behzadi, E.: The microbial agents of urinary tract infections at central laboratory of Dr. Shariati Hospital, Tehran, Iran. Turkiye Klinikleri J Med Sci 28, 445-449 (2008).

113. Behzadi, E., Behzadi, P., Ranjbar, R.: In vitro apoptotic activity of UVB light in Klebsiella pneumoniae. Alban Med J 2, 18-22 (2014).

114. Jarchum, I., Pamer, E. G.: Regulation of innate and adaptive immunity by the commensal microbiota. Curr Opin Immunol 23, 353-360 (2011). DOI: 10.1016/j.coi.2011.03.001 
115. Littman, D. R., Pamer, E. G.: Role of the commensal microbiota in normal and pathogenic host immune responses. Cell Host Microbe 10, 311-323 (2011). DOI: 10.1016/j. chom.2011.10.004

116. Mal, X., Trinchieri, G.: Regulation of interleukin-12 production in antigen-presenting cells. Adv Immunol 79, 55-92 (2001). DOI: 10.1016/S0065-2776(01)79002-5

117. Kroenke, M. A., Carlson, T. J., Andjelkovic, A. V., Segal, B. M.: IL-12- and IL-23-modulated T cells induce distinct types of EAE based on histology, CNS chemokine profile, and response to cytokine inhibition. JEM 205, 1535-1541 (2008). DOI: 10.1084/ jem.20080159

118. Zhou, L., Ivanov, I. I., Spolski, R., Min, R., Shenderov, K., Egawa, T., Levy, D. E., Leonard, W. J., Littman, D. R.: IL-6 programs TH-17 cell differentiation by promoting sequential engagement of the IL-21 and IL-23 pathways. Nat Immunol 8, 967-974 (2007). DOI: $10.1038 /$ ni1488

119. Croxford, A. L., Mair, F., Becher, B.: IL-23: One cytokine in control of autoimmunity. Eur J Immunol 42, 2263-2273 (2012). DOI: 10.1002/eji.201242598

120. O'Shea, J. J., Plenge, R.: JAK and STAT signaling molecules in immunoregulation and immune-mediated disease. Immunity 36, 542-550 (2012). DOI: 10.1016/j.immuni.2012. 03.014

121. Devergne, O., Birkenbach, M., Kieff, E.: Epstein-Barr virus-induced gene 3 and the p35 subunit of interleukin 12 form a novel heterodimeric hematopoietin. Proc Natl Acad Sci 94, 12041-12046 (1997).

122. Pflanz, S., Timans, J. C., Cheung, J., Rosales, R., Kanzler, H., Gilbert, J., Hibbert, L., Churakova, T., Travis, M., Vaisberg, E.: IL-27, a heterodimeric cytokine composed of $\mathrm{EBI} 3$ and p28 protein, induces proliferation of naive $\mathrm{CD}^{+} \mathrm{T}$ cells. Immunity $\mathbf{1 6}, 779$ 790 (2002). DOI: 10.1016/S1074-7613(02)00324-2

123. Abdalla, A. E., Li, Q., Xie, L., Xie, J.: Biology of IL-27 and its role in the host immunity against Mycobacterium tuberculosis. Int J Biol Sci 11, 168 (2015). DOI: 10.7150/ ijbs.10464

124. Hunter, C. A., Kastelein, R.: Interleukin-27: balancing protective and pathological immunity. Immunity 37, 960-969 (2012). DOI: 10.1016/j.immuni.2012.11.003

125. Pirhonen, J., Sirén, J., Julkunen, I., Matikainen, S.: IFN- $\alpha$ regulates Toll-like receptormediated IL-27 gene expression in human macrophages. J Leukoc Biol 82, 1185-1192 (2007). DOI: 10.1189/jlb.0307157

126. Liu, J., Guan, X., Ma, X.: Regulation of IL-27 p28 gene expression in macrophages through MyD88- and interferon- $\gamma$-mediated pathways. JEM 204, 141-152 (2007). DOI: 10.1084/jem.20061440

127. Zhang, J., Qian, X., Ning, H., Yang, J., Xiong, H., Liu, J.: Activation of IL-27 p28 gene transcription by interferon regulatory factor 8 in cooperation with interferon regulatory factor 1. J Biol Chem 285, 21269-21281 (2010). DOI: 10.1074/jbc.M110.100818

128. Pot, C., Apetoh, L., Kuchroo, V. K.: Type 1 regulatory T cells (Tr1) in autoimmunity. In: editor. editors. Seminars in immunology. Semin Immunol 23(3): 202-208 (2011). DOI: 10.1016/j.smim.2011.07.005

129. Wojno, E. D. T., Hunter, C. A.: New directions in the basic and translational biology of interleukin-27. Trends Immunol 33, 91-97 (2012). DOI: 10.1016/j.it.2011.11.003

130. Owaki, T., Asakawa, M., Kamiya, S., Takeda, K., Fukai, F., Mizuguchi, J., Yoshimoto, T.: IL-27 suppresses CD28-medicated IL-2 production through suppressor of cytokine signaling 3. J Immunol 176, 2773-2780 (2006). DOI: 10.4049/jimmunol.176.5.2773 
131. Rosas, L. E., Satoskar, A. A., Roth, K. M., Keiser, T. L., Barbi, J., Hunter, C., de Sauvage, F. J., Satoskar, A. R.: Interleukin-27R (WSX-1/T-cell cytokine receptor) gene-deficient mice display enhanced resistance to Leishmania donovani infection but develop severe liver immunopathology. Am J Pathol 168, 158-169 (2006). DOI: 10.2353/ajpath.2006. 050013

132. Hölscher, C., Hölscher, A., Rückerl, D., Yoshimoto, T., Yoshida, H., Mak, T., Saris, C., Ehlers, S.: The IL-27 receptor chain WSX-1 differentially regulates antibacterial immunity and survival during experimental tuberculosis. J Immunol 174, 3534-3544 (2005). DOI: 10.4049/jimmunol.174.6.3534

133. Villarino, A. V., Huang, E., Hunter, C. A.: Understanding the pro- and anti-inflammatory properties of IL-27. J Immunol 173, 715-720 (2004). DOI: 10.4049/jimmunol.173.2.715

134. Yoshida, H., Hamano, S., Senaldi, G., Covey, T., Faggioni, R., Mu, S., Xia, M., Wakeham, A. C., Nishina, H., Potter, J.: WSX-1 is required for the initiation of Th1 responses and resistance to L. major infection. Immunity 15, 569-578 (2001). DOI: 10.1016/S10747613(01)00206-0

135. Chen, Q., Ghilardi, N., Wang, H., Baker, T., Xie, M.-H., Gurney, A., Grewal, I. S., de Sauvage, F. J.: Development of Th1-type immune responses requires the type I cytokine receptor TCCR. Nature 407, 916-920 (2000). DOI: 10.1038/35038103

136. Guzzo, C., Mat, N. F. C., Gee, K.: Interleukin-27 induces a STAT1/3- and NF-кBdependent proinflammatory cytokine profile in human monocytes. J Biol Chem 285, 24404-24411 (2010). DOI: 10.1074/jbc.M110.112599

137. Hibbert, L., Pflanz, S., de Waal Malefyt, R., Kastelein, R. A.: IL-27 and IFN- $\alpha$ signal via Stat 1 and Stat 3 and induce T-Bet and IL-12R $\beta 2$ in naive T cells. J Interferon Cytokine Res 23, 513-522 (2003). DOI: 10.1089/10799900360708632

138. Kamiya, S., Owaki, T., Morishima, N., Fukai, F., Mizuguchi, J., Yoshimoto, T.: An indispensable role for STAT1 in IL-27-induced T-bet expression but not proliferation of naive $\mathrm{CD}^{+}{ }^{+} \mathrm{T}$ cells. J Immunol 173, 3871-3877 (2004). DOI: 10.4049/jimmunol.173.6.387

139. Lucas, S., Ghilardi, N., Li, J., de Sauvage, F. J.: IL-27 regulates IL-12 responsiveness of naive $\mathrm{CD}^{+} \mathrm{T}$ cells through Statl-dependent and -independent mechanisms. Proc Natl Acad Sci 100, 15047-15052 (2003). DOI: 10.1073/pnas.2536517100

140. Collison, L. W., Delgoffe, G. M., Guy, C. S., Vignali, K. M., Chaturvedi, V., Fairweather, D., Satoskar, A. R., Garcia, K. C., Hunter, C. A., Drake, C. G.: The composition and signaling of the IL-35 receptor are unconventional. Nat Immunol 13, 290-299 (2012). DOI: $10.1038 /$ ni.2227

141. Garbers, C., Aparicio-Siegmund, S., Rose-John, S.: The IL-6/gp130/STAT3 signaling axis: recent advances towards specific inhibition. Curr Opin Immunol 34, 75-82 (2015). DOI: 10.1016/j.coi.2015.02.008

142. Dittrich, A., Hessenkemper, W., Schaper, F.: Systems biology of IL-6, IL-12 family cytokines. Cytokine Growth Factor Rev 26, 595-602 (2015). DOI: 10.1016/j.cytogfr. 2015.07.002

143. Boulay, J.-L., O’Shea, J. J., Paul, W. E.: Molecular phylogeny within type I cytokines and their cognate receptors. Immunity 19, 159-163 (2003). DOI: 10.1016/S1074-7613 (03)00211-5

144. Mihara, M., Hashizume, M., Yoshida, H., Suzuki, M., Shiina, M.: IL-6/IL-6 receptor system and its role in physiological and pathological conditions. Clin Sci 122, 143-159 (2012). DOI: $10.1042 / C S 20110340$ 
145. Mihara, M., Nishimoto, N., Ohsugi, Y.: The therapy of autoimmune diseases by anti-interleukin-6 receptor antibody. Expert Opin Biol Ther 5, 683-690 (2005). DOI: 10.1517/ 14712598.5.5.683

146. Wong, P. K., Campbell, I. K., Egan, P. J., Ernst, M., Wicks, I. P.: The role of the interleukin- 6 family of cytokines in inflammatory arthritis and bone turnover. Arthritis Rheum 48, 1177-1189 (2003). DOI: 10.1002/art.10943

147. Pflanz, S., Hibbert, L., Mattson, J., Rosales, R., Vaisberg, E., Bazan, J. F., Phillips, J. H., McClanahan, T. K., de Waal Malefyt, R., Kastelein, R. A.: WSX-1 and glycoprotein 130 constitute a signal-transducing receptor for IL-27. J Immunol 172, 2225-2231 (2004). DOI: 10.4049/jimmunol.172.4.2225

148. Boulanger, M. J., Chow, D.-C., Brevnova, E. E., Garcia, K. C.: Hexameric structure and assembly of the interleukin-6/IL-6 $\alpha$-receptor/gp130 complex. Science 300, 2101-2104 (2003). DOI: 10.1126/science.1083901

149. Lee, S.-Y., Jung, Y. O., Kim, D.-J., Kang, C.-M., Moon, Y.-M., Heo, Y.-J., Oh, H.-J., Park, S.-J., Yang, S.-H., Kwok, S. K.: IL-12p40 Homodimer ameliorates experimental autoimmune arthritis. J Immunol 195, 3001-3010 (2015). DOI: 10.4049/jimmunol.1500400

150. Gillessen, S., Carvajal, D., Ling, P., Podlaski, F. J., Stremlo, D. L., Familletti, P. C., Gubler, U., Presky, D. H., Stern, A. S., Gately, M. K.: Mouse interleukin-12 (IL-12) p40 homodimer: a potent IL-12 antagonist. Eur J Immunol 25, 200-206 (1995). DOI: 10.1002/ eji. 1830250133 